\title{
Guanacastepene-A total synthesis: construction of the tricyclic iso-guanacastepane, epi-guanacastepane and guanacastepane frameworks
}

\author{
Goverdhan Mehta,* Jayant D. Umarye and Kalidindi Srinivas \\ Department of Organic Chemistry, Indian Institute of Science, Bangalore 560 012, India
}

\begin{abstract}
Studies aimed towards the total synthesis of the diterpene antibiotic, guanacastepene A, of current interest and displaying promising biological activity against drug resistant pathogens has led to the generation of some novel tricyclic skeleta replete with extensive functionalization and representing interesting variations of the guanacastepane framework.
\end{abstract}

Guanacastepene A 1, a diterpene with a novel carbon skeleton (guanacastepane), was isolated from an unidentified endophytic fungus growing on the tree Daphnopsis americana by Clardy et al. ${ }^{\text {la }}$ in 2000 and its structure was determined by X-ray crystallography. More recently, several additional guanacastepenes $\mathrm{B}-\mathrm{O}$ have been isolated from the same fungus and structurally characterized. ${ }^{1 \mathrm{~b}}$ Guanacastepene A $\mathbf{1}$ has been shown to exhibit impressive activity against methicillin-resistant Staphylococcus aureus and vancomycin resistant Enterococcus faecium. Additional, biological studies on 1 have unravelled moderate activity against Gram-positive bacteria, poor activity against Gramnegative bacteria and haemolytic activity against human RBC. ${ }^{\text {lc }}$ While these latter attributes undermine the therapeutical potential of $\mathbf{1}$, its promising profile against MRSA and VREF has stimulated an intensive world-wide search for synthetic and naturally occurring analogues.

The 5,7,6-ring fused tricarbocyclic framework of $\mathbf{1}$, with attendant network of functionalities and stereochemical subtleties, makes it a formidable synthetic target. Thus, on account of its biological potential and synthetic challenge, nearly a dozen research groups have been enticed into the $\mathrm{fray}^{2-4}$ in the quest for guanacastepene A 1. While Danishefsky et al. ${ }^{4}$ have been the first to reach the milestone and achieved a total synthesis of $\mathbf{1}$ in 2002, others have unfolded strategies leading to the acquisition of bicyclic and tricyclic core structures of $1 .^{2-4} \mathrm{We}$ too have entered this arena and reported model studies ${ }^{3 a}$ leading to the bicyclic hydroazulenic core of guanacastepene $A$ and further extended ${ }^{3 b}$ these studies to acquire its fully functionalized and stereochemically secured $\mathrm{AB}$ and BC ring segments, $\mathbf{2}$ and $\mathbf{3}$, respectively. Our synthetic approach towards $\mathbf{1}$, from the beginning, was aimed at imparting substantial structural, functional and stereochemical latitude to enable access to diverse analogues of the natural product in view of its biological potential. Herein, we report our further synthetic explorations in the area that have resulted in the acquisition of tricyclic iso-guanacastepane, epi-guanacastepane and guanacastepane derivatives, representing novel skeletal and functional group analogues and variants of 1 .
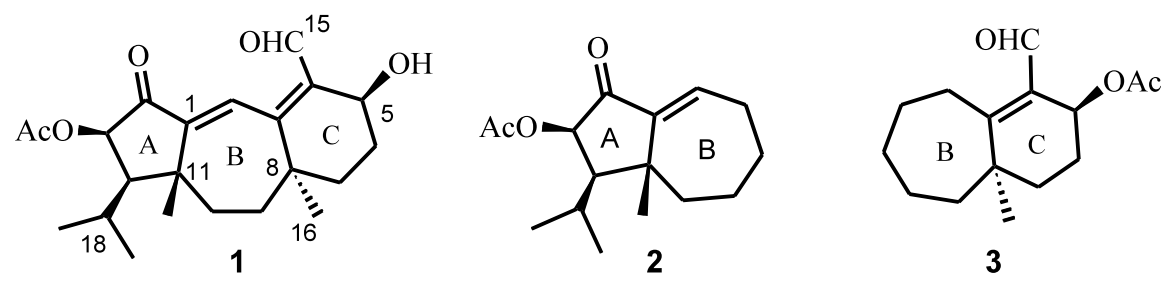

\footnotetext{
* Corresponding author.
} 


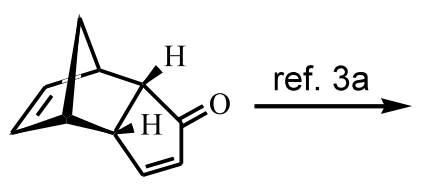

4<smiles>CC(C)C1C(=O)C=C2CCC=CC21C</smiles>

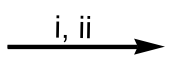<smiles>CCCCC12CCCCC1=C[C@@H](O)C2C(C)C</smiles>

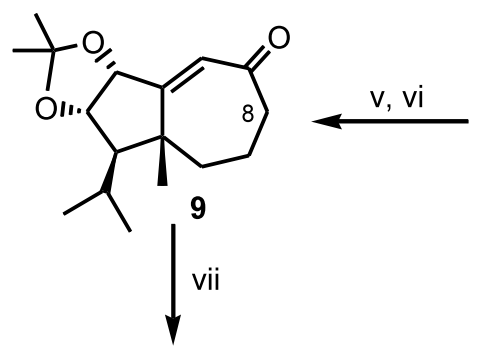<smiles>CC(C)C1C2CCCC=C2[C@@H](O)[C@H]1O</smiles>

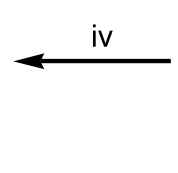<smiles>CC(C)C1[C@H](O)[C@H]2O[C@@]13CCCCC[C@]23C</smiles>

7
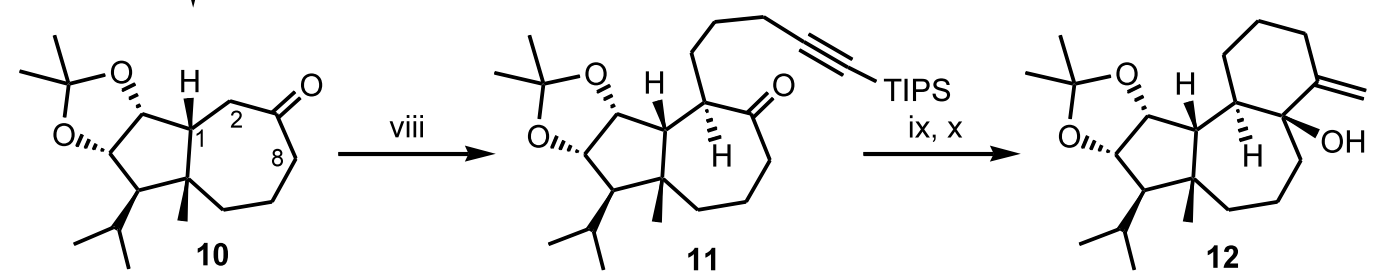

Scheme 1. Reagents and conditions: (i) $10 \% \mathrm{Pd} / \mathrm{C}, \mathrm{H}_{2}$, EtOAc, 98\%; (ii) DIBAL-H, DCM, 98\%; (iii) MCPBA, DCM, 92\%; (iv) pyridine, TMSOTf, DMAP, 75-80\%; (v) DMP, acetone, PPTS, 95\%; (vi) 3,5-dimethylpyrazole, $\mathrm{CrO}_{3}, \mathrm{DCM}, 50 \%$; (vii) 10\% Pd/C, $\mathrm{H}_{2}$, EtOAc, 80\%; (viii) LDA, THF, HMPA, I $\left(\mathrm{CH}_{2}\right)_{3} \mathrm{CCTIPS},-78^{\circ} \mathrm{C}-\mathrm{rt}, 12 \mathrm{~h}, 30 \%$; (ix) $\mathrm{TBAF}, \mathrm{moist} \mathrm{THF}$, rt, 95\%; (x) Na-naphthalenide, THF, $90 \%$.

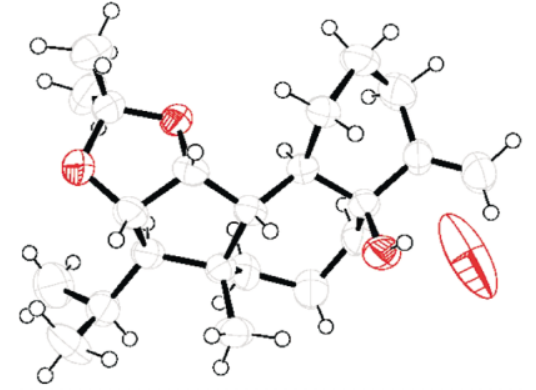

Figure 1.

Our first foray was targeted towards the construction of the tricyclic guanacastepane skeleton by annulation of a six-membered ring onto a hydroazulenic precursor following the earlier ${ }^{3 b}$ model study that led to the realization of 3. However, the implementation of the projected reaction sequence resulted in a regiochemical deviation and led to the novel isoguanacastepane skeleton. Hydroazulenic enone 5, readily available through a short sequence $^{3 \mathrm{a}}$ from tricyclic enone $\mathbf{4}$ was elaborated to 6 through selective catalytic hydrogenation of the isolated double bond and stereoselective enone reduction (Scheme 1). This stereoselective reduction is somewhat anomalous with hydride addition exclusively from the same face as the $\beta$-isopropyl and $\beta$-methyl groups and is in accordance with earlier observations in similar systems. ${ }^{3 \mathrm{a}, 4}$ Stereoselective epoxidation of $\mathbf{6}$ led to 7 and TMSOTf mediated epoxide opening furnished the cisenediol 8 (Scheme 1). ${ }^{5}$ Acetonide protection of the cis-diol in $\mathbf{8}$ and allylic oxidation ${ }^{6}$ furnished $\mathbf{9}^{5}$ in which we had a versatile precursor that had in place the key oxy-functionalization in the A-ring and the olefinic bond in the B-ring as required in the natural product 1. Therefore the main task ahead was the annulation of the six-membered C-ring and for this purpose several strategies (vide infra) were explored.

Repeated efforts to alkylate 9 at the desired C-8 position with tris-isopropylsilyl protected 5-iodo-1-pentyne or other alkylating agents to set-up the planned six-ring annulation $^{3 \mathrm{~b}}$ proved abortive. While this effort was in progress others also reported similar observations. ${ }^{2,4}$ Recourse was then taken to the reduced product $\mathbf{1 0}$ of 9, which could be alkylated regioselectively with trisisopropylsilyl protected 5-iodo-1-pentyne to furnish $\mathbf{1 1}^{5}$ via C-2 alkylation rather than at the required C-8 position (Scheme 1). Silyl deprotection of $\mathbf{1 1}$ and sodium naphthalenide mediated intramolecular alkyneketone cyclization ${ }^{3 b}$ proceeded with excellent stereoselectivity and in high yield to furnish 12 (Scheme 1). A single crystal X-ray structure determination ${ }^{7}$ of $\mathbf{1 2}$ confirmed the site of alkylation in $\mathbf{1 0}$ and consequent acquisition of the new 5,7,6-fused tricyclic (iso-guanacastepane) skeleton (Fig. 1).

Attention was now turned to address the crucial issue of alkylation of the enone 9 at the C-8 position. It was observed that 9 could be $\alpha$-carboethoxylated at the C-8 position employing Mander's reagent ${ }^{8}$ to yield 13, which could be further allylated stereoselectively (vide infra) and in good yield to 14 (Scheme 2). Addition of 


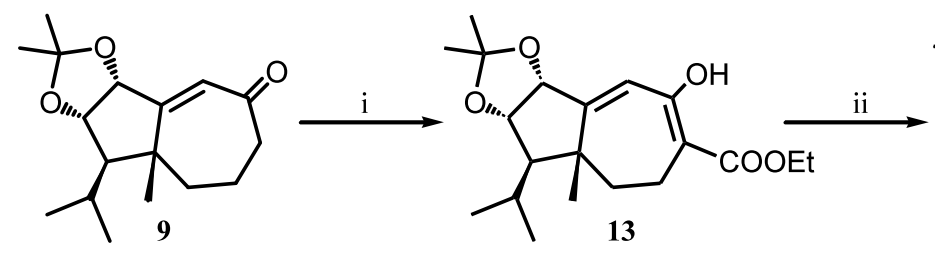<smiles>C=CC[C@@]1(O)C=C2[C@@H]3OC(C)(C)O[C@H]3C(C(C)C)C2(C)CC[C@]1(CC=C)C(=O)OCC</smiles>

Scheme 2. Reagents and conditions: (i) LDA, THF-HMPA, CNCOOEt, $-78^{\circ} \mathrm{C}, 75 \%$; (ii) NaH, THF, allyl bromide, rt, $95 \%$; (iii) $\mathrm{Mg}$, 3-chloro-1-butene, $\mathrm{CeCl}_{3}$, THF, 60\%; (iv) Grubbs' catalyst (10 mol\%), benzene, $\Delta, 96 \%$; (v) DIBAL-H, DCM, 65\%.

the Grignard reagent prepared from 3-chloro-1-butene to $\mathbf{1 4}$ in the presence of cerium(III) chloride ${ }^{9}$ proceeded stereoselectively to furnish $\mathbf{1 5}^{5}$ and set the stage for the contemplated RCM protocol for the construction of the six-membered C-ring of guanacastepene (Scheme 2). Indeed, exposure of $\mathbf{1 5}$ to Grubbs' catalyst resulted in smooth conversion to the tricyclic compound $\mathbf{1 6}$ in high yield (Scheme 2). ${ }^{5}$ Reduction of 16 with DIBAL-H resulted not only in the reduction of the ester functionality to a primary alcohol but quite unexpectedly also reductively cleaved the acetonide moiety to yield $\mathbf{1 7}$ (Scheme 2). An X-ray crystal structure determination ${ }^{7}$ of 17 firmly established its stereochemistry and indicated that it was epimeric at C-8 with respect to the natural guanacastepanes and that the allylation of $\mathbf{1 3}$ had preferentially occurred from the less hindered $\alpha$ face. However, in a short sequence it was possible to transform the bicyclic ketone 9 into the $\mathrm{C}_{20}$-skeleton corresponding to epi-guanacastepane with a rich complement of functionalities in all the three rings (Fig. 2).<smiles>CCOC(=O)C1=C(O)C=C2[C@@H]3OC(C)(C)O[C@@H]3C(C(C)C)C2(C)CC1</smiles><smiles>CCOC(=O)[C@]1(C)CC[C@]2(C)C(=CC1=O)[C@@H]1OC(C)(C)O[C@H]1C2C(C)C</smiles><smiles>C=C[C@H](C)[C@]1(O)C=C2[C@@H]3OC(C)(C)O[C@@H]3C(C(C)C)[C@@]2(C)CC[C@]1(C)C(=O)OCC</smiles><smiles>C/C=C\CC(O)[C@@]1(C)CCC2(C)C(=CC1=O)[C@H]1OC(C)(C)O[C@H]1C2C(C)C</smiles>

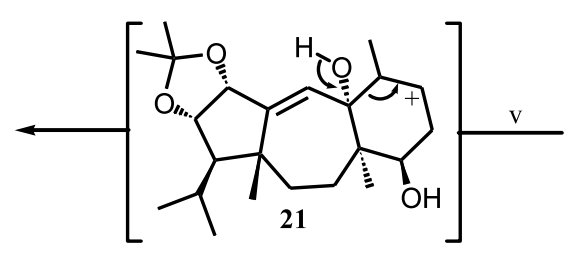

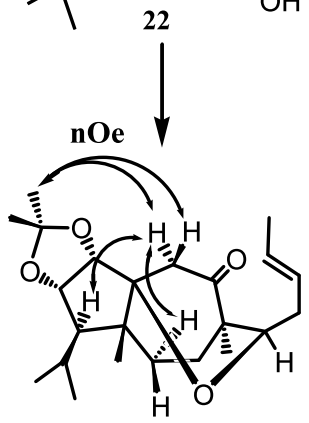

23

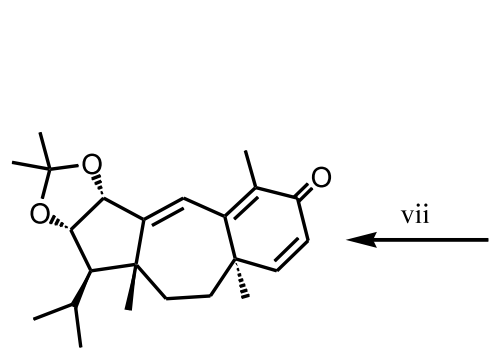

25

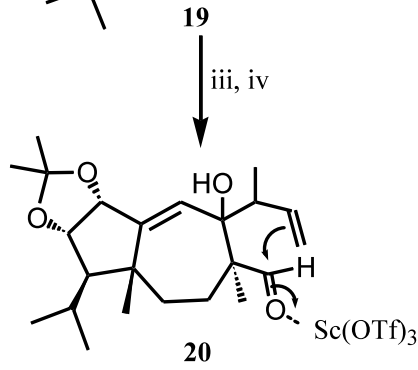

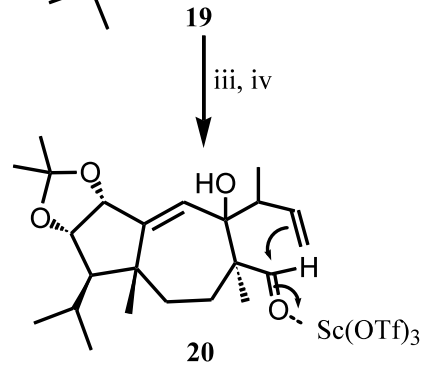

vi<smiles>CC(C)C1[C@H]2OC(C)(C)O[C@H]2C2=CC3(O)C(C)C(C)(O)OC(O)[C@@]3(C)CCC21C</smiles>

24

Scheme 3. Reagents and conditions: (i) NaH, THF, MeI, 85-90\%; (ii) $\mathrm{Mg}$, 3-chloro-1-butene, $\mathrm{CeCl}_{3}, \mathrm{THF}, 70 \%$; (iii) $\mathrm{LAH}, \mathrm{THF}$,

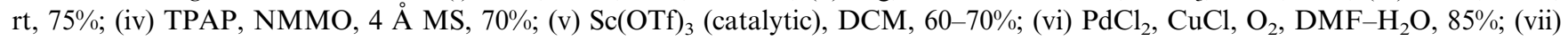
$\mathrm{NaOEt}, \mathrm{EtOH}, \mathrm{rt}, 40-50 \%$. 


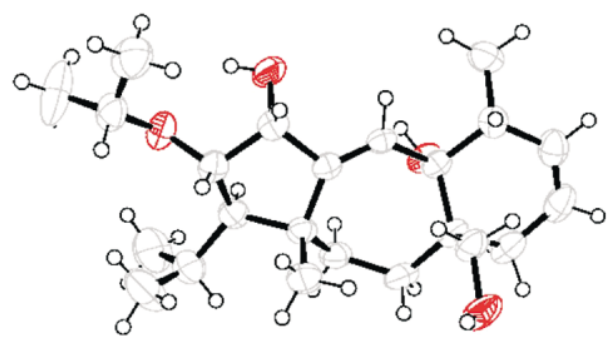

Figure 2.

The epimeric nature of $\mathbf{1 7}$ at C-8 indicated that the way to generate the correct stereochemistry present in the natural guanacastepanes was to harness the carboethoxy group in $\mathbf{1 3}$ in the C-ring forming protocols. Towards this end $\mathbf{1 3}$ was methylated to furnish 18 and correctly install the C-8 quaternary centre with the methyl group in the $\alpha$-orientation and trans with respect to the pre-existing C-11 angular methyl group (Scheme 3). Addition of the Grignard reagent derived from 3-chloro-1-butene to $\mathbf{1 8}$ in the presence of cerium(III) chloride was chemoselective and furnished 19. ${ }^{5}$ The ester group in $\mathbf{1 9}$ was now elaborated via LAH reduction and $n$-tetrapropylammonium per-ruthenate (TPAP) oxidation to aldehyde $\mathbf{2 0},{ }^{5}$ in preparation for its integration into the proposed six-membered ring. For this purpose, an intramolecular Prins-type cyclization in $\mathbf{2 0}$ with several Lewis acids was explored but without much success. We therefore turned to a recent report where $\mathrm{Sc}(\mathrm{OTf})_{3}$ had been found to be effective in inducing aldehyde-ene cyclization. ${ }^{10}$ Consequently, 20 was exposed to $\mathrm{Sc}(\mathrm{OTf})_{3}$ and the reaction took an interesting course. We found that 22, a seco-guanacastepane derivative, was formed first via the fragmentation of the initially generated aldehyde-ene cyclization intermediate 21. Continued exposure of 22 to the reaction milieu resulted in further intramolecular cyclization to the interesting bridged ether $23,{ }^{5}$ whose stereostructure was secured through detailed 2D NMR (COSY, NOE) studies (Scheme 3). As a consequence of this unanticipated albeit interesting deviation, we had to alter our strategy. Wacker oxidation of the terminal olefinic bond in $\mathbf{2 0}$ led to the hydrate $\mathbf{2 4}$, an appropriate candidate for effecting aldol cyclization to generate the C-ring of guanacastepanes. In the event, stirring $\mathbf{2 4}$ with sodium ethoxide in ethanol led to the desired cyclization and concomitant dehydration to yield an extremely interesting cross conjugated trienone $\mathbf{2 5}^{5}$ with the complete guanacastepane framework and a high level of functionalization (Scheme 3). It is to be noted that the cross-conjugated trienone functionality present in $\mathbf{2 5}$ is quite unique and may impart some useful biological attributes to this molecule.

In summary, we have achieved a synthesis of the 5,7,6fused tricyclic framework of guanacastepane diterpenes, replete with requisite stereochemical features and extensive functionalization, from a hydroazulenic precursor with the focus on the exploration of different six-ring annulation strategies. Our efforts have also provided access to new tricyclic structural variants (iso-guanacastepane and epi-guanacastepane) of the biologically promising guanacastepene A $\mathbf{1}$.

\section{Acknowledgements}

J.D.U. and K.S. thank CSIR for the award of a research fellowship. We also acknowledge the help from SIF at the IISc towards obtaining high field NMR spectral data. X-ray data were collected at the CCD facility at IISc.

\section{References}

1. (a) Brady, S. F.; Singh, M. P.; Janso, J. E.; Clardy, J. J. Am. Chem. Soc. 2000, 122, 2116; (b) Brady, S. F.; Bondi, S. M.; Clardy, J. J. Am. Chem. Soc. 2001, 123, 9900; (c) Singh, M. P.; Janso, J. E.; Luckman, S. W.; Brady, S. F.; Clardy, J.; Greenstein, M.; Maiese, W. M. J. Antibiot. 2000, 53, 256.

2. (a) Snider, B. B.; Hawryluk, N. A. Org. Lett. 2001, 3, 569; (b) Dudley, G. B.; Danishefsky, S. Org. Lett. 2001, 3, 2399; (c) Dudley, G. B.; Tan, D. S.; Kim, G.; Tanski, J. M.; Danishefsky, S. J. Tetrahedron Lett. 2001, 42, 6789; (d) Magnus, P.; Waring, M. J.; Ollivier, C.; Lynch, V. Tetrahedron Lett. 2001, 42, 4947; (e) Snider, B. B.; Shi, B. Tetrahedron Lett. 2001, 42, 9123; (f) Shipe, W. D.; Sorensen, E. J. Org. Lett. 2002, 4, 2063; (g) Nguyen, T. M.; Lee, D. Tetrahedron Lett. 2002, 43, 4033; (h) Boyer, F.-D.; Hanna, I. Tetrahedron Lett. 2002, 43, 7469; (i) Nakazaki, A.; Sharma, U.; Tius, M. A. Org. Lett. 2002, 4, 3363; (j) Nguyen, T. M.; Seifert, R. J.; Mowrey, D. R.; Lee, D. Org. Lett. 2002, 4, 3959; (k) Magnus, P.; Ollivier, C. Tetrahedron Lett. 2002, 43, 9605.

3. (a) Mehta, G.; Umarye, J. D. Org. Lett. 2002, 4, 1063; (b) Mehta, G.; Umarye, J. D.; Gagliardini, V. Tetrahedron Lett. 2002, 43, 6975.

4. (a) Tan, D. S.; Dudley, G. B.; Danishefsky, S. J. Angew. Chem., Int. Ed. 2002, 41, 2185; (b) Lin, S.; Dudley, G. B.; Tan, D. S.; Danishefsky, S. J. Angew. Chem., Int. Ed. 2002, 41, 2188.

5. All new compounds reported here are racemic and were duly characterized on the basis of spectral (IR, ${ }^{1} \mathrm{H}$ and ${ }^{13} \mathrm{C}$ NMR) and analytical data. Selected spectral data: Compound 12: IR $\left(\mathrm{cm}^{-1}\right)$ : 3449, 1645; ${ }^{1} \mathrm{H}$ NMR (300 $\left.\mathrm{MHz}, \mathrm{CDCl}_{3}\right): \delta 4.99(\mathrm{~s}, 1 \mathrm{H}), 4.77(\mathrm{~s}, 1 \mathrm{H}), 4.42-4.31(\mathrm{~m}$, $2 \mathrm{H}), 2.24-2.07(\mathrm{~m}, 4 \mathrm{H}), 1.90-1.84(\mathrm{~m}, 2 \mathrm{H}), 1.72-1.50$ (series of m, 8H), $1.49(\mathrm{~s}, 3 \mathrm{H}), 1.27(\mathrm{~s}, 3 \mathrm{H}), 1.27-1.25(\mathrm{~m}$, 1H), $1.16-1.08(\mathrm{~m}, 1 \mathrm{H}), 1.02-1.00$ (brs, 9H); ${ }^{13} \mathrm{C}$ NMR $\left(75 \mathrm{MHz}, \mathrm{CDCl}_{3}\right): \delta 158.6,109.5,107.0,82.2,82.1,60.7$, $51.8,46.7,43.4,42.9,39.3,29.5,28.8,26.4,26.2,26.0$, $25.4,24.3,23.5,21.2,19.2$. Compound 16: IR $\left(\mathrm{cm}^{-1}\right)$ : 3519, 1730; ${ }^{1} \mathrm{H}$ NMR $\left(300 \mathrm{MHz}, \mathrm{CDCl}_{3}\right): \delta 5.84(\mathrm{~d}$, $J=1.5 \mathrm{~Hz}, 1 \mathrm{H}), 5.63-5.58(\mathrm{~m}, 1 \mathrm{H}), 5.35$ (brd, $J=10.2$ $\mathrm{Hz}, 1 \mathrm{H}), 4.87(\mathrm{~d}, J=7.2 \mathrm{~Hz}, 1 \mathrm{H}), 4.37$ (dd as t, $J=7.2$ $\mathrm{Hz}, 1 \mathrm{H}), 4.05$ (q, $J=7.5 \mathrm{~Hz}, 2 \mathrm{H}), 2.84-2.82(\mathrm{~m}, 1 \mathrm{H})$, $2.51-2.41(\mathrm{~m}, 2 \mathrm{H}), 2.34(\mathrm{dd}, J=18.6,3.0 \mathrm{~Hz}, 1 \mathrm{H}), 2.67-$ $2.20(\mathrm{~m}, 1 \mathrm{H}), 1.85-1.82(\mathrm{~m}, 1 \mathrm{H}), 1.78$ (brs, 1H), 1.74-1.66 $(\mathrm{m}, 1 \mathrm{H}), 1.48(\mathrm{~s}, 3 \mathrm{H}), 1.43-1.36(\mathrm{~m}, 1 \mathrm{H}), 1.36(\mathrm{~s}, 3 \mathrm{H})$, $1.20(\mathrm{t}, J=7.5 \mathrm{~Hz}, 3 \mathrm{H}), 1.12(\mathrm{~d}, J=7.2 \mathrm{~Hz}, 3 \mathrm{H}), 1.04$ (d, 
$J=6.6 \mathrm{~Hz}, 3 \mathrm{H}), 0.98(\mathrm{~d}, J=6.6 \mathrm{~Hz}, 3 \mathrm{H}), 0.86(\mathrm{~s}, 3 \mathrm{H}) ;{ }^{13} \mathrm{C}$ NMR $\left(75 \mathrm{MHz}, \mathrm{CDCl}_{3}\right): \delta 175.8,150.6,131.6,125.5$, $123.6,112.4,82.8,80.2,72.6,61.6,60.2,54.1,49.5,40.2$, $37.0,36.7,33.8,28.1,27.9,26.2,23.6,22.4,18.8,14.0$, 13.9; HRMS calcd for: $\mathrm{C}_{25} \mathrm{H}_{38} \mathrm{O}_{5} \mathrm{Na}\left(\mathrm{MNa}^{+}\right)$: 441.2671 . Found: 441.2629. Compound 20: IR $\left(\mathrm{cm}^{-1}\right)$ : 3494, 1713; ${ }^{1} \mathrm{H}$ NMR $\left(300 \mathrm{MHz}, \mathrm{CDCl}_{3}\right): \delta 9.78(\mathrm{~s}, 1 \mathrm{H}), 5.78-5.66$ $(\mathrm{m}, 1 \mathrm{H}), 5.52(\mathrm{~s}, 1 \mathrm{H}), 5.09-5.02(\mathrm{~m}, 2 \mathrm{H}), 4.79(\mathrm{~d}, J=6.9$ $\mathrm{Hz}, 1 \mathrm{H}), 4.42(\mathrm{dd}$ as $\mathrm{t}, J=7.2 \mathrm{~Hz}, 1 \mathrm{H}), 2.89-2.79(\mathrm{~m}$, $1 \mathrm{H}), 2.53(\mathrm{~s}, 1 \mathrm{H}), 2.04-1.99(\mathrm{~m}, 2 \mathrm{H}), 1.90-1.85(\mathrm{~m}, 1 \mathrm{H})$, 1.80-1.68 (m, 2H), 1.64-1.59 (m, 1H), 1.49 (s, 3H), 1.35 $(\mathrm{s}, 3 \mathrm{H}), 1.31(\mathrm{~s}, 3 \mathrm{H}), 1.08(\mathrm{~d}, J=6.0 \mathrm{~Hz}, 3 \mathrm{H}), 1.07$ (d, $J=6.6 \mathrm{~Hz}, 3 \mathrm{H}), 1.04(\mathrm{~d}, J=6.6 \mathrm{~Hz}, 3 \mathrm{H}), 1.00(\mathrm{~s}, 3 \mathrm{H}) ;{ }^{13} \mathrm{C}$ NMR $\left(75 \mathrm{MHz}, \mathrm{CDCl}_{3}\right): \delta$ 207.9, 145.3, 141.1, 134.4, $117.7,111.8,82.0,81.9,81.8,63.2,53.3,49.3,47.0,34.5$, 28.3, 26.7, 26.1, 25.1, 24.6, 21.8, 20.4, 17.4, 16.6; HRMS calcd for $\mathrm{C}_{23} \mathrm{H}_{36} \mathrm{O}_{4} \mathrm{Na}\left(\mathrm{MNa}^{+}\right)$: 399.2511. Found: 399.2500; Compound 23: IR $\left(\mathrm{cm}^{-1}\right)$ : 1720,$970 ;{ }^{1} \mathrm{H}$ NMR $\left(400 \mathrm{MHz}, \mathrm{CDCl}_{3}\right): \delta 5.54-5.43(\mathrm{~m}, 2 \mathrm{H}), 4.50(\mathrm{~d}, J=8.0$ $\mathrm{Hz}, 1 \mathrm{H}), 4.24(\mathrm{dd}, J=8.4,5.6 \mathrm{~Hz}, 1 \mathrm{H}), 3.76(\mathrm{dd}, J=7.6$, $4.0 \mathrm{~Hz}, 1 \mathrm{H}), 2.71(1 / 2 \mathrm{ABq}, J=19.6 \mathrm{~Hz}, 1 \mathrm{H}), 2.40$ $2 \mathrm{ABq}, J=19.6 \mathrm{~Hz}, 1 \mathrm{H}), 2.22-2.15(\mathrm{~m}, 1 \mathrm{H}), 2.00-1.88(\mathrm{~m}$, $3 \mathrm{H}), 1.72-1.67(\mathrm{~m}, 1 \mathrm{H}), 1.65(\mathrm{~d}, J=4.4 \mathrm{~Hz}, 3 \mathrm{H}), 1.62$ $1.58(\mathrm{~m}, 1 \mathrm{H}), 1.47(\mathrm{~s}, 3 \mathrm{H}), 1.37(\mathrm{dt}, J=14.8,4.0 \mathrm{~Hz}, 1 \mathrm{H})$, $1.30(\mathrm{~s}, 3 \mathrm{H}), 1.27-1.23(\mathrm{~m}, 1 \mathrm{H}), 1.03(\mathrm{~s}, 6 \mathrm{H}), 0.99(\mathrm{~d}$, $J=6.4 \mathrm{~Hz}, 3 \mathrm{H}), 0.92(\mathrm{~d}, J=6.4 \mathrm{~Hz}, 3 \mathrm{H}) ;{ }^{13} \mathrm{C}$ NMR $(75$ $\left.\mathrm{MHz}, \mathrm{CDCl}_{3}\right): \delta 212.1,128.1,127.1,112.7,85.3,84.6$, $82.7,82.0,60.3,52.5,51.0,42.2,38.7,38.3,34.9,29.5$, 25.9, 24.7, 22.7, 22.4, 20.4, 18.0, 16.0; HRMS calcd for: $\mathrm{C}_{23} \mathrm{H}_{36} \mathrm{O}_{4} \mathrm{Na}\left(\mathrm{MNa}^{+}\right)$: 399.2511. Found: 399.2526. Compound 25: IR $\left(\mathrm{cm}^{-1}\right)$ : 1658, 1625; ${ }^{1} \mathrm{H}$ NMR (400 MHz, $\left.\mathrm{CDCl}_{3}\right): \delta 6.71(\mathrm{~d}, J=9.6 \mathrm{~Hz}, 1 \mathrm{H}), 6.33(\mathrm{~s}, 1 \mathrm{H}), 6.23(\mathrm{~d}$, $J=9.6 \mathrm{~Hz}, 1 \mathrm{H}), 4.88(\mathrm{~d}, J=6.4 \mathrm{~Hz}, 1 \mathrm{H}), 4.44(\mathrm{dd}$ as t, $J=6.8 \mathrm{~Hz}, 1 \mathrm{H}), 2.00-1.92(\mathrm{~m}, 1 \mathrm{H}), 1.85(\mathrm{~s}, 3 \mathrm{H}), 1.78$ $1.64(\mathrm{~m}, 5 \mathrm{H}), 1.53(\mathrm{~s}, 3 \mathrm{H}), 1.37(\mathrm{~s}, 3 \mathrm{H}), 1.27(\mathrm{~s}, 3 \mathrm{H}), 1.06$ (d, $J=6.4 \mathrm{~Hz}, 3 \mathrm{H}), 1.01(\mathrm{~d}, J=6.4 \mathrm{~Hz}, 3 \mathrm{H}), 0.86(\mathrm{~s}, 3 \mathrm{H})$; ${ }^{13} \mathrm{C}$ NMR (100 MHz, $\left.\mathrm{CDCl}_{3}\right): \delta 186.1,157.2,152.5$,
132.3, 126.6 (brd), 124.4, 112.0, 82.8, 81.4 (brd), 34.5 (brd), 31.9 (brd), 29.7, 28.3, 27.4, 26.1, 24.2, 21.9, 11.5; HRMS calcd for $\mathrm{C}_{23} \mathrm{H}_{32} \mathrm{O}_{3} \mathrm{Na}\left(\mathrm{MNa}^{+}\right)$: 379.2249 . Found: 379.2268 .

6. Salmond, W. G.; Barta, M. A.; Havens, H. L. J. Org. Chem. 1978, 43, 2057.

7. Crystal data for compound 12: Structure was solved by direct methods (SIR92). Refinement was by full-matrix least-squares using SHELXL-97. Crystal system: monoclinic, space group: $C 2 / c$, cell parameters: $a=9.882(1)$, $b=21.732(3), \quad c=20.003 \quad$ (3) $\AA ; \quad \beta=102.709(3)^{\circ} ; \quad V=$ $4190.98 \AA^{3}, \quad Z=8.0, \quad F(000)=1568.0, \quad \mu=0.07 \mathrm{~mm}^{-1}$, $D_{\text {calcd }}=1.13, \lambda=0.7107 \AA$. Total number of 1.s. parameters $=375, R_{1}=0.0874$ for $1517 F_{\mathrm{o}}>4 \sigma\left(F_{\mathrm{o}}\right)$ and 0.2519 for all 4213 data. GOF $(S)=0.972$, restrained $\mathrm{GOF}=0.972$ for all data. An ORTEP diagram (with trapped water molecule) with $50 \%$ ellipsoidal probability of compound 12 is shown in Figure 1, CCDC No. 205947.

Crystal data for compound 17: Structure was solved by direct methods (SIR92). Refinement was by full-matrix least-squares using SHELXL-97. Crystal system: monoclinic, space group: $P 2(1) / c$, cell parameters: $a=7.1824$ (7), $b=17.096$ (1), $c=17.994$ (1) $\AA$; $\beta=92.759$ (2) $; V=$ $2207.03 \AA^{3}, \quad Z=4.0, \quad F(000)=832.0, \quad \mu=0.08 \mathrm{~mm}^{-1}$, $D_{\text {calcd }}=1.139, \lambda=0.7107 \AA$. Total number of 1.s. parameters $=396, R_{1}=0.0530$ for $3070 F_{\mathrm{o}}>4 \sigma\left(F_{\mathrm{o}}\right)$ and 0.0664 for all 3731 data. GOF $(S)=1.105$, restrained $\mathrm{GOF}=1.105$ for all data. An ORTEP diagram with 50\% ellipsoidal probability of compound $\mathbf{1 7}$ is shown in Figure 2, CCDC No. 205714.

8. Mander, L. N.; Sethi, S. P. Tetrahedron Lett. 1983, 24, 5425.

9. Imamoto, T.; Takiyama, N.; Nakamura, K.; Hatajima, T.; Kamiya, Y. J. Am. Chem. Soc. 1989, 111, 4392.

10. Aggarwal, V. K.; Vennall, G. P.; Davey, P. N.; Newman, C. Tetrahedron Lett. 1998, 39, 1997. 